\title{
Never have a crisis like COVID-19
}

\author{
Yongseok Jang ${ }^{1}$, and Woojin Lee ${ }^{2 *}$ \\ 1 California State University San Bernardino, 5500 University Parkway, San Bernardino 92407 \\ 2 Kookmin Universsity, 77, Jeongneung-ro, Seongbuk-gu, Seoul, South Korea
}

\begin{abstract}
Current circumstances caused by COVID-19 pandemic pose a unique challenge to businesses. How could businesses survive? What strategic options do businesses have when they effectively engage such a challenge? Delving into the inquiry, we explore and investigate different strategic approaches to measure their effectiveness. For the study's explorative and investigative purposes, our investigation involves a set of tests at both business and corporate levels. Using 224 responses from the leaders and key individuals of Korean startups, we tested the effectiveness of strategic options using the notion of ambidexterity and alliances, and mergers and acquisitions. Using the ambidexterity lens, we found exploitation and exploration indirectly affect firm performances and are still effective under COVID-19. We also found "reinforcing the relationship with existing alliances," a corporate-level approach, to be effective.
\end{abstract}

Keywords: Ambidexterity, COVID-19, crisis management, corporate strategy

\section{Introduction}

In times of external shock, firms face different types of crises, such as the reduction of consumer surplus, mostly stem from a combination of loss of customer and reflected as a loss of revenue, or reduction of producers' surplus, which is derived by a few factors such as loss of suppliers and loss of key employees, etc. Current circumstance caused by COVID-19 pandemic poses a unique challenge to businesses. First, it is a combination of natural and economic crisis, compared to 2008 financial crisis which was caused by a massive disruption of financial sector. Second, for the first reason, policy measures countering health risks, such as banning public events, lockdown, and shutdowns, followed and consequently put business at risks of losing customers and supply/distribution channels. In this case, businesses face a dual crisis. First, the crisis strikes internal stakeholders-the health risk of owners and employee. Second, externally, businesses get to struggle by the reduced foot traffic and business infrastructure due to travel restriction. Third, on top of the magnitude of the crisis, the crisis comes with a wide scope and the impact of which is omnipresence, thus making relocation or changing the target markets irrelevant and ineffective options [1].

How could businesses survive? What strategic options do businesses have when they effectively engage such a challenge? In a recent virtual special issue published in Strategic Management Society, strategic options are categorized into four types, retrenchment,

* Corresponding author: drlee@kookmin.ac.kr 
preserving, innovating, and exit. Exit means the discontinuation of the business before the situation goes out of control, and some suggest as a best way to cope with a crisis [2]. Exit may appear a forced outcome, but help businesses save resources for a new project they might develop in the future [3]. Decision to discontinue their business is also up to the context. Based on given findings that businesses are less likely to exit when they face natural disasters [4], it is questionable whether exit is still a valuable option for businesses facing challenges by COVID-19. While exit is in fact widely practiced, we decide not to consider it due to limited accessibility to the business that exited. Instead, we replace exit with another approach that firms can take to respond to the crisis. This approach is corporate-level strategy, such as making new alliances, increasing the number of alliances, or mergers and acquisitions (M\&A).

Delving into the inquiry, in this study, we explore and investigate different strategic approaches to measure their effectiveness. For both explorative and investigative purposes of the study, our investigation involves a set of tests at both business level and corporate level. Literature has tested strategic ambidexterity as a key to understanding the role of dynamic capability in times of crisis and found that exploration is effective in adaptation, not exploitation [5,6]. Given proven relevance, ambidexterity framework is therefore employed as a proper lens to assess business-level strategy. Corporate strategies are considered in multiple angels, but mostly focusing on alliance, M\&A. The aim of the study, in this sense, is to present a few pragmatic implications that would help business in responding to a crisis like COVID-19 pandemic.

We find research gap in a multiple dimension, which further signifies the study. First, we see a lack of understanding of how entrepreneurs use multiple strategic tools effectively to address challenges imposed by the external crisis, like COVID-19. Second, regarding the literature of ambidexterity, heterogeneous characteristics of crises are not well accounted for. Despite the difference in origins and natures, external shocks are treated as a backdrop or a treatment that has no effect on firms.

Using 224 responses collected from the leaders and key individuals of Korean startups, we tested the effectiveness of strategic options using the notion of ambidexterity and alliances, and M\&A. In the following section, we develop testable model based on our strategic perspective and present what we found from empirical investigation. A brief discussion will conclude our paper with a few potentials for further development.

\section{Conceptual model}

Focusing on the effect of strategic option, we believe firm performance is function of a combination of operational efficiency and level of innovation. Strategic responses are chosen and employed when firms face external shock and the effectiveness of which is tested regarding the firm's financial performance recorded in the following fiscal year. As briefly explained, borrowing the framework of ambidexterity, the construct of "exploitation" is used to measure the effectiveness of "retrenchment." Likewise, the construct, exploration is used for "innovating." We measure the change of both strategies to measure "preserving." Finally, corporate level strategies are measured at three dimensions, which are reinforcing existing alliances, establishing and increasing new alliances, and finally M\&A. We consider businesslevel strategies as mediators as firms tend to be forced to choose them given pathdependency. In other words, firms with a high level of operating efficiency find "exploitation" easy to pursue and the same for the other. We consider corporate strategies as moderators as decisions made at corporate are relevantly free from the firm characteristics rather it is driven by fit of resource and capability between the partners. In this model, both business and corporate level strategies are considered treatment, thus used observation of the year 2020, causing the outcome of the following year. The baseline model considers the direct 
relationship between firm characteristics measured by two dimensions, operating efficiency and innovativeness, and financial performance of 2021, one year after the strategic measures were treated. Figure 1 shows our conceptual model that incorporates both ambidexterity and corporate level strategy.

\section{Theory and Hypothesis}

\subsection{Effectiveness of business level strategies}

While our focus is on the treatment effect of the focused strategies, we believe the firm performance is largely predicted by two widely accepted two strategic determinants [7], firm innovativeness, and operational efficiency. Using the two pillars that play a pivotal role for firms to create a core capability, we believe testing the effectiveness of the two constructs to find out if they still work during a time of crisis is relevant. As for the first construct, innovativeness is widely known as a good predictor of firm performance [8,9], which refers to firm wide efforts directed toward business renovation, including the development of new products/services and innovating the existing business model with an aim to attain a sustainable competitive advantage [7]. Operating efficiency is also widely known as a good predictor of firm performance [10], which refers to the firm's wide capability to improve the productivity of standard operating procedures to achieve maximum productivity and thus gain and sustain a competitive advantage [7]. The opposite is still true. Firms' inefficiencies are attributed to suboptimal use of resources, such as overpaying for inputs [11]. Operational efficiency benefits firms, particularly when firms get involved with risk management [12]. We call a combination of these two constructs, hereafter, the firm capabilities as they are generally endogenous factors constant to the firm regardless of a specific external context such as a crisis. We hypothesize therefore that these two firm capabilities predict financial performance even during the time of COVID-19.

Hypothesis 1. Firm capabilities (innovativeness and operating efficiencies) have direct effect on the firm performance.

Focusing on the interaction of the strategies, we move on our focus on the first strategic options firm can take in response to a crisis, retrenchment. Retrenchment refers to a strategic response to an externa shock, where business attempt to focus on managing efficiencies when they must deal with a net loss $[13,14]$. Aligning to the strategic management literature, this study determines that "retrenchment" corresponds to exploitation, a strategy provided by ambidexterity frameworks. We hypothesize exploitation strategy moderate the effect of firm capabilities of firms.

Hypothesis 1a. Exploitation strategy would mediate the relationship between firm characteristics and firm performance.

The second option we discussed earlier was preserving. Preserving refers simply maintaining the status quo and mitigate the impact of the crisis [15], which implies that firms undermining significance of path-dependency might experience hard time in a time of crisis [16]. According to strategies preserving is the safest option especially for firms facing great level of uncertainty. We hypothesize that maintaining the same strategy would moderate the effect of firm capabilities of firms.

Hypothesis $1 b$. Preserving strategy would mediate the relationship between firm characteristics and firm performance. 
Another strategy to be tested is undertaking strategic renewal by innovating the way they used to. Innovating business involves widening the business scope by exploring uncharted sectors or new ways of doing business, therefore allow firms to try an alternative market and business opportunities and help firms respond to a crisis [17]. Research found, however, innovation is effective for firms can utilize lack resource and complementary assets [18]. Note that a precondition of "innovating" is extra resource, which is rare to startups, leaving innovating a valuable option for young and small organizations [19]. Again, we found "innovating" corresponds to the other strategic option, exploration. We hypothesize exploring strategy moderate the effect of firm capabilities of firms.

Hypothesis 1c. Exploration strategy would mediate the relationship between firm characteristics and firm performance.

\subsection{Effectiveness of corporate level strategies}

Partnership and alliances are different from exit as it is a voluntary action that involves "exchange, coordination, sharing, and/or joint development of resources and capabilities" [20]. Partnership and alliances appear to be useful when firms face challenges as they are found to be effective in providing incremental resources [21], and in helping firms diversify [22] as crisis mostly comes with disrupted environmental munificence (abundance of resource available to firms) and disappearance of existing markets [23]. We hypothesize alliance strategy would help firm address uncertain environment. We measure the effect in two dimensions.

First, we contend reinforcing the relations with existing alliances moderate the effect of firm capabilities of firms.

Hypothesis 2a. Reinforcing the relations with existing alliances would moderate the relationship between firm characteristics and firm performance.

Second, we further hypothesize exploring and establishing new alliances moderate the effect of firm capabilities of firms.

Hypothesis 2b. Exploring and establishing new alliance would moderate the relationship between firm characteristics and firm performance.

M\&A largely refer corporate level strategies which involves higher level of risk because it requires major resource commitments [24]. Responding to crises, firms may pursue M\&A with the aim to achieve decreased competitors to ease industry-level degree of rivalry. Further, the acquisition allows firms to exploit new opportunities presented by environmental disruption [25]. We hypothesize M\&A would moderate the effect of firm capabilities of firms.

Hypothesis 2c. Mergers and acquisitions would moderate the relationship between firm characteristics and firm performance. 


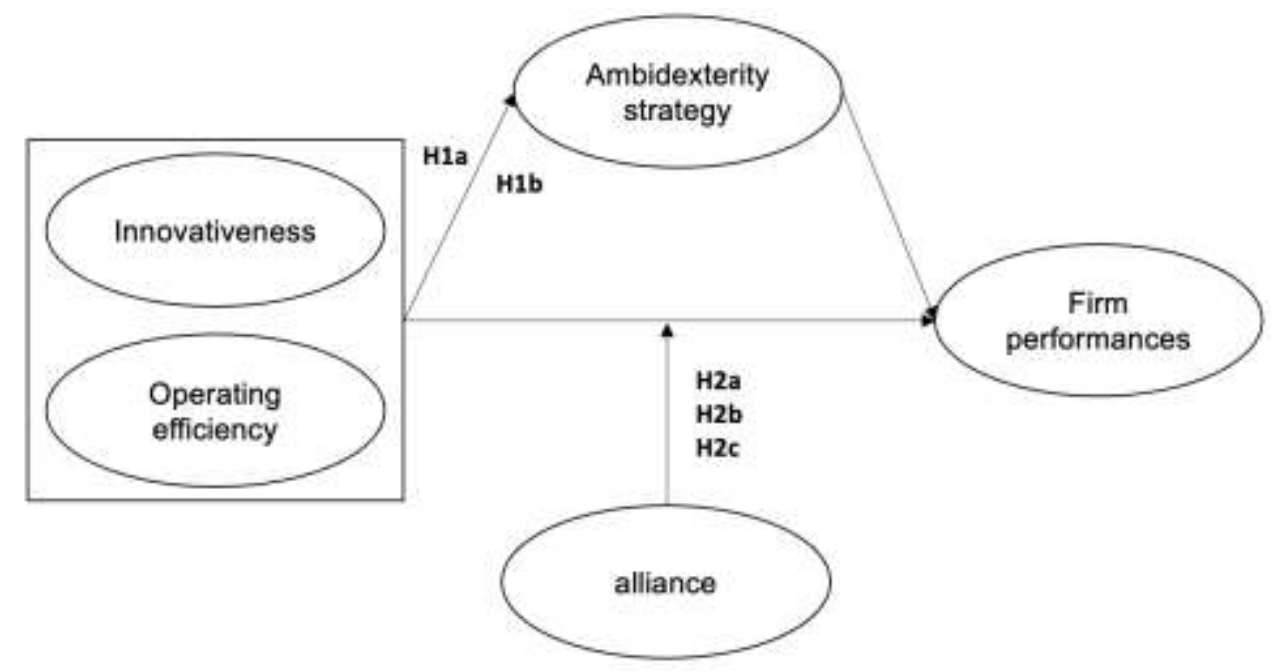

Fig 1. The proposed model

Source: Own processing

\section{Method}

\subsection{Data Collection}

For the purpose of the study, we conducted an online survey and collected data from the leaders and key individuals of startups registered of South Korean the Korean Startup Forum and Youth Startup Academy in 2021 (April to Jun) . Korea Startup Forum (KSF) is the nation's largest startup membership organization with active members of more than 1,500 startups and partners. Youth Startup Academy is a public organization supported by Korean SME agency (KOSME), which is dedicated to discover early-stage startups with innovative technologies to support them by providing total package programs to grow them into successful startup companies. In total, 800 companies were invited to participate in this study. The survey questionnaires were distributed to each startup's CEO and/or founder, or team leader, who has a high level of understanding about firm's strategy and circumstances. After cleaning incomplete responses, overall, we collected 224 usable responses.

\subsection{Measures}

Participants were asked to rate several aspects of strategic orientation and firm characteristics they know of the firm using the following scales. If not indicated otherwise, all scales used a five-point Likert scale ranging from 1 (strongly disagree) to 5 (strongly agree). Table 1 provides overall information about our measures.

\subsubsection{Dependent variable}

We measured firm performance based on the respondents' perceptional evaluations on their financial performances for a set of three financial indicators, such as annual revenue growth, operating profit, and return on investment. The respondents were asked to provide relevant information of pre-pandemic period, specifically 2021. It our attention to use year 2021's financial performance as an outcome of strategic responses they took in 2020. 


\subsubsection{Independent variable}

Innovativeness is measured a set of eight items to collect information about strategic intensity of firm to engage in R\&D. Using the same approach, Operating efficiency is measured by eight items scale. After conducting principal component analysis, two items were dropped for cross loading. The respondents were asked to provide relevant information of prepandemic period, specifically 2019. It our attention to use pre-pandemic strategic capability of firms as a controlled context.

\subsubsection{Focused Mediators}

The focused mediators are both exploration and exploitation. We asked the respondents to reflect their strategic intensity on activities to explore and exploit during 2020, they took as strategic responses to respond to the crisis using four item scale to measure both constructs. As a proxy of "preserving," we created a variable to measure how much increase or decrease they made to the strategic intensity of both exploration and exploitation. We find very marginal differences ranging from -.3 to .3 . The respondents were asked to provide relevant information of 2012. It our attention to consider them as strategic responses to counter the situation caused by COVID-19.

\subsubsection{Focused Moderators}

To measure moderating effect of corporate level strategy, respondents rated on three items; a) if they have reinforced relationship they have with existing alliances and partners, b) if they have established new alliances and c) if they have undertaken M\&A.

Table 1. Variable Description

\begin{tabular}{|c|c|c|}
\hline & Operational Definition & Measures \\
\hline $\begin{array}{c}\text { Control } \\
\text { variables }\end{array}$ & $\begin{array}{l}\text { Age - a period in which startup was established } \\
\text { Revenue - Annual sales before COVID-19 }\end{array}$ & \\
\hline $\begin{array}{l}\text { Independent } \\
\text { variables }\end{array}$ & $\begin{array}{l}\text { Innovativeness - degree to develop the product } \\
\text { process and business model } \\
\text { Operating efficiency - capacity to improve } \\
\text { productivity of standard procedure, technology skills, } \\
\text { quality of product/service }\end{array}$ & 5-points Likert \\
\hline Mediators & $\begin{array}{l}\text { Exploration strategy- degree to discover, explore and } \\
\text { develop new things } \\
\text { Exploitation strategy - degree to maximize efficiency } \\
\text { by improving existing technologies and capabilities } \\
\text { Preserving - degree to maintaining strategy }\end{array}$ & 5-points Likert \\
\hline Moderators & $\begin{array}{l}\text { Existing alliance - degree of strengthening } \\
\text { partnerships with existing companies } \\
\text { New alliance - degree of strengthening partnerships } \\
\text { with new companies } \\
\text { Mergers and acquisition - degree to which mergers and } \\
\text { acquisition are attempted with competitors and affiliates }\end{array}$ & 5-points Likert \\
\hline $\begin{array}{l}\text { Dependent } \\
\text { variables }\end{array}$ & $\begin{array}{l}\text { Performance }- \text { An increase in total revenue, such as } \\
\text { total sales, ROS, investment profit of startup }\end{array}$ & $\begin{array}{l}\bigcirc, 120 \% \text { decreased } \sim \\
\text { O,520\%increased }\end{array}$ \\
\hline
\end{tabular}

Source: Own processing 


\section{Analysis and Results}

\subsection{Hypothesis Testing}

Table 2 presents the means, standard deviations, and inter-correlations among the variables under study. Operational efficiency is positively correlated with firm performance $(r=.619$, $\mathrm{p}<.01)$. There was no significant correlation relationship between innovativeness and firm performance $(\mathrm{r}=.097, \mathrm{~ns})$. Operating capabilities positively correlated with exploration $(\mathrm{r}=$ $.419, \mathrm{p}<.01)$ and exploitation $(\mathrm{r}=.437, \mathrm{p}<.01)$ as a mediator, but not with preserving $(\mathrm{r}=$ $.033, \mathrm{~ns})$.

Table 2. Descriptive and Correlations of Variables from Probationary Participants

\begin{tabular}{|c|c|c|c|c|c|c|c|}
\hline Variable & $M$ & $S D$ & 1 & 2 & 3 & 4 & 5 \\
\hline 1. Age & 4.05 & 1.99 & 1.00 & & & & \\
\hline 2. Revenue & 1.76 & 1.10 & $0.306^{* * *}$ & & & & \\
\hline 3. Innovativeness & 3.76 & 0.761 & 0.042 & -0.047 & & & \\
\hline $\begin{array}{l}\text { 4. Operating } \\
\text { capabilities }\end{array}$ & 3.81 & 0.664 & $0.025^{* *}$ & -0.064 & $0.619^{* * *}$ & & \\
\hline 5. Exploration & 7.07 & 2.03 & -0.006 & $-0.135^{*}$ & $0.365^{* * *}$ & $0.419^{* * *}$ & \\
\hline 6. Exploitation & 0.00 & 0.09 & 0.121 & -0.097 & $0.377^{* * *}$ & $0.437^{* * *}$ & $0.764^{* * *}$ \\
\hline 7. Preserving & 0.492 & 0.559 & 0.026 & 0.043 & 0.054 & 0.033 & $-0.206^{* *}$ \\
\hline 8. Alliance 1 & 3.41 & 1.30 & 0.006 & $-0.186^{* *}$ & $0.255^{* * *}$ & $0.348^{* * *}$ & $0.689^{* * *}$ \\
\hline 9. Alliance 2 & 3.40 & 1.26 & 0.03 & $-0.122 *$ & $0.288^{* * *}$ & $0.377^{* * *}$ & $0.648^{* * *}$ \\
\hline 10. Alliance 3 & 2.29 & 1.38 & -0.004 & 0.064 & $0.21^{* *}$ & 0.023 & $0.322^{* * *}$ \\
\hline $\begin{array}{l}\text { 11. Firm } \\
\text { performance }\end{array}$ & 3.02 & 1.16 & $-0.161^{* *}$ & 0.041 & 0.097 & $0.222^{* * *}$ & -0.062 \\
\hline
\end{tabular}

\begin{tabular}{lccccc}
\hline & 6 & 7 & 8 & 9 & 10 \\
\hline 7. Preserving & $0.256^{* * *}$ & & & & \\
8. Alliance 1 & $0.618^{* * *}$ & -0.06 & & & \\
9. Alliance 2 & $0.66^{* * *}$ & 0.043 & $0.802^{* * *}$ & & \\
10. alliance 3 & $0.255^{* * *}$ & -0.079 & $0.339^{* * *}$ & $0.415^{* * *}$ & \\
11. Firm & -0.061 & 0.078 & -0.078 & -0.08 & -0.103 \\
\hline \multicolumn{1}{l}{ performance } & & & & & \\
\hline
\end{tabular}

Chybí source

We began our analysis by examining the means, standard deviations (SD), and correlations for our variables. Table 2 provides descriptive statistics and Pearson correlation of the variables. Hypothesis 1 proposed that ambidexterity (exploitation/exploration/preserving) strategy might mediate the relationship between firm characteristics and firm performance. Moderation tests showed that after controlling for company age, company revenue, exploitation strategy was negatively mediated between operational characteristics and firm performance $(\beta=-.16, p<.05)$. Thus, Hypothesis 1a was supported. Exploration strategy was also negatively mediated to firm performance $(\beta=-.198$, $\mathrm{p}<.05$ ). Hypothesis $1 \mathrm{c}$ was supported. However, preserving strategy was not significantly related to operation capabilities and firm performance. Hypothesis $1 \mathrm{~b}$ was not supported (Table 3). 
Table 3. Regression Results for Mediation Effect of ambidexterity strategy on Operational efficiency and Firm performances

\begin{tabular}{|c|c|c|c|c|c|c|c|c|c|}
\hline & $\begin{array}{l}\text { Dependent } \\
\text { Variables }\end{array}$ & $\begin{array}{c}\text { Independent } \\
\text { Variables }\end{array}$ & $\beta$ & $\begin{array}{c}\text { Std. } \\
\text { Error }\end{array}$ & $\mathrm{t}$ value & $P$ & $\overline{\mathrm{R}^{2}}$ & $\operatorname{adj} . R^{2}$ & $\begin{array}{c}\text { F- } \\
\text { statistics }\end{array}$ \\
\hline \multirow[t]{3}{*}{$\begin{array}{c}\text { Step } \\
1\end{array}$} & $\begin{array}{c}\text { Firm } \\
\text { performance }\end{array}$ & (intercept) & & & & & & & \\
\hline & & Innovativeness & $\begin{array}{c}- \\
0.086\end{array}$ & 0.125 & -0.685 & 0.494 & \multirow{2}{*}{0.091} & \multirow{2}{*}{0.075} & \multirow{2}{*}{5.503} \\
\hline & & $\begin{array}{l}\text { Operating } \\
\text { efficiency }\end{array}$ & 0.471 & 0.144 & $3.278 * *$ & 0.001 & & & \\
\hline \multirow[t]{3}{*}{$\begin{array}{c}\text { Step } \\
2\end{array}$} & Exploration & $\begin{array}{l}\text { Operating } \\
\text { efficiency }\end{array}$ & 0.649 & 0.096 & 6.745 & 0.000 & 0.223 & 0.213 & 21.11 \\
\hline & Preserving & $\begin{array}{l}\text { Operating } \\
\text { efficiency }\end{array}$ & 0.005 & 0.009 & 0.486 & 0.627 & 0.003 & -0.01 & 0.224 \\
\hline & Exploitation & $\begin{array}{l}\text { Operating } \\
\text { efficiency }\end{array}$ & 0.713 & 0.100 & 7.094 & 0.000 & 0.214 & 0.2035 & 19.99 \\
\hline \multirow[t]{3}{*}{$\begin{array}{c}\text { Step } \\
3\end{array}$} & $\begin{array}{c}\text { Firm } \\
\text { performance }\end{array}$ & $\begin{array}{l}\text { Operating } \\
\text { efficiency }+ \\
\text { exploration }\end{array}$ & $0 . \overline{198}$ & 0.078 & -2.540 & 0.012 & 0.116 & 0.100 & 7.217 \\
\hline & & $\begin{array}{c}\text { Operating } \\
\text { efficiency }+ \\
\text { Preserving }\end{array}$ & 0.913 & 0.809 & 1.128 & 0.260 & 0.094 & 0.07811 & 5.723 \\
\hline & & $\begin{array}{l}\text { Operating } \\
\text { efficiency }+ \\
\text { exploitation }\end{array}$ & $0 . \overline{169}$ & 0.075 & -2.257 & 0.025 & 0.110 & 0.093 & 6.773 \\
\hline
\end{tabular}

Source: Authors' current study.

We discussed the moderating effects of existing alliance, new alliance, and the M\&A separately. Table 4 shows the results of the moderation. Existing alliance was found to moderate the effect of operational efficiency on firm performance $(\mathrm{B}=.236, \mathrm{SE}=.082, \mathrm{t}=2.885, \mathrm{p}<.05)$. Moderation test with autonomy showed that the interaction between operating capabilities and new alliance did not significantly affect firm perform ace $(\mathrm{B}=.13, \mathrm{SE}=.084, \mathrm{t}=1.539, \mathrm{p}=.125)$. Hypothesis $2 \mathrm{~b}$ did not receive support. Moderation test with the M\&A showed that M\&A did not affect the relationship between operating capabilities and firm performance $(\mathrm{B}=.035, \mathrm{SE}=.082$, $\mathrm{t}=.429, \mathrm{p}=.668$ ). Thus, hypothesis $2 \mathrm{c}$ did receive support.

Table 4. Regression Results for Moderation Effect of Alliance on Operational capabilities and Firm performances

\begin{tabular}{|l|c|c|c|c|c|}
\hline & $\boldsymbol{\beta}$ & $\boldsymbol{S E}$ & $\boldsymbol{t}$ value & $\boldsymbol{P}$ & supported \\
\hline Operation capabilities & -0.23368 & 0.28117 & -0.831 & 0.40684 & \\
\hline Existing alliance & -1.06767 & 0.32608 & -3.274 & 0.00123 & \\
\hline OC $\times$ existing allice & 0.23582 & 0.08173 & $2.885^{* *}$ & 0.0043 & Supported \\
\hline Model $R^{2}$ & \multicolumn{5}{|c|}{0.143} \\
\hline adj. $R^{2}$ & 0.1243 \\
\hline F-statistics & \multicolumn{5}{|c|}{0.33} \\
\hline Operation capabilities & 0.11008 & 0.2937 & 0.375 & 0.70816 & \\
\hline New alliance & -0.66673 & 0.33479 & -1.991 & 0.04768 & \\
\hline OC $\times$ existing allice & 0.12973 & 0.0843 & 1.539 & 0.12526 & Not Supported \\
\hline Model $R^{2}$ & \multicolumn{5}{|c|}{0.124} \\
\hline adj. $R^{2}$ & \multicolumn{5}{|c|}{0.105} \\
\hline F-statistics & 6.215 & \\
\hline Operation capabilities & 0.33423 & 0.22139 & 1.51 & 0.1326 & \\
\hline Merger \& Acquisition & -0.23929 & 0.33294 & -0.719 & 0.4731 & \\
\hline
\end{tabular}




\begin{tabular}{|l|c|c|c|c|c|}
\hline OC $\times$ existing allice & 0.0354 & 0.08249 & 0.429 & 0.6683 & Not Supported \\
\hline Model $R^{2}$ & \multicolumn{5}{|c|}{0.103} \\
\hline adj. $R^{2}$ & 0.083 & \\
\hline F-statistics & 5.049 & \\
\hline
\end{tabular}

Source: Authors' current study.

\section{Conclusion and Discussion}

In this study, we have explored multiple strategic responses available startups to counter the current pandemic and investigated their effectiveness. We explored three strategic options available to startups, retrenchment, preserving, and innovation. Using ambidexterity lens, exploitation and exploration were used as a set of relevant constructs for retrenchment and innovation, respectively. Consistent with previous literature, we found business response to changing the situation at business level still effective, except preserving. Given long lasting COVID-19, our finding seems to be consistent with what we already know about retrenchment [26, 27].

Not all corporate level approach turned out to be effective, but "reinforcing the relationship with existing alliances." It implies that under the circumstance of COVID19, operational efficiency may benefit from existing partnerships. Making new alliances, on the other hand, may only increase the level of uncertainty that is already high. The effectiveness of M\&A may be explained by the relatively scarce resource slack available to startups [22].

This study makes a few meaningful contributions. First, we presented the validity of ambidexterity lens to the context of young startups. Ambidexterity has been studied largely for established business, a relevance of which has been barely applied to the context of entrepreneurial venture. Partly, it was because resource constraints of young startups would drive them into a focused approach, instead of trying two approaches. Our study, we believe, opened a potential possibility of ambidexterity approach for young startups. Second, our study extended the applicability of the ambidexterity lens by examining its validity in the context of the current pandemic. As stated earlier, pandemic, COVID-19 imposed a new set of uncertainty and constraints, we never experienced in a recent history, where businesses are left unguided with which strategic options, they can take addressing the challenge. Presenting the effectiveness of exploitation and exploration, we are confident to suggest business could consider them to try, a managerial implication we make. Second, our study calls for attention to the corporate level strategy, especially the significance of exiting alliance during a time of crisis, to scholars of entrepreneurship research. Corporate-level strategy is largely considered strategic options applicable for large established ones, but our finding says otherwise. Maintaining a close relationship with existing alliances would benefit young startups. Third, during a time of crisis, our findings show that firms should benefit from both business level and corporate level strategies as they are not mutually exclusive to each other. Finally, but not least, our study adds to the literature of crisis management and among a few that tested the effectiveness of strategic responses in the time of COVID-19, the pandemic, a type of crisis humanity never experienced in a recent modern history. We hope that we paved a way for future research stream in this venue. As not all studies are perfect, our studies left room for future development. First, while our study shed light on the role of alliances, we admit that our findings only scratch the surface. We are limited in presenting the detailed story behind it, including the purpose of reinforcing relationships with existing partners, whether it could be to control uncertainty or enter into some sort of smaller scale clan. Future research might make use of secondary data that provide industry restructuring during the pandemic may help us unfold what truly happened during the time. Second, as this study relied heavily on subjective evaluations of the respondents, we ran a risk of forgoing accuracy 
of the measurement. In our defense, our focus is more on strategic effectiveness, the evaluations of which is often made by the CEO and individuals involved in strategic decisions. Besides, we believe our approach is effective enough in laying out a foundation for further investigation.

\section{References}

1. M. Wenzel, H. Krämer, J. Koch, A. Reckwitz, Future and organization studies: On the rediscovery of a problematic temporal category in organizations. Organization Studies, 41(10), 1441-1455 (2020)

2. L. Dai, L. Eden, P. Bemish, Caught in the crossfire: Dimensions of vulnerability and foreign multinationals' exit from war-afflicted countries. Strategic Management Journal, 38(7), 1478-1498 (2017)

3. S. Carnahan, Blocked but not tackled: Who founds new firms when rivals dissolve? Strategic Management Journal, 38(11), 2189-2212 (2017)

4. C. Oh, J. Oetzel, Multinationals' response to major disasters: how does subsidiary investment vary in response to the type of disaster and the quality of country governance? Strategic Management Journal, 32(6), 658681 (2011)

5. A. Gupta, K. Smith, C. Shalley, The interplay between exploration and exploitation. Academy of Management Journal, 49(4), 693-706 (2006)

6. O. Osiyevskyy, G. Shirokova, G, P. Ritala, Exploration and exploitation in crisis environment: Implications for level and variability of firm performance. Journal of Business Research, 114, 227-239 (2020)

7. J. Lee, H. Kwon, N. Pati, Exploring the relative impact of R\&D and operational efficiency on performance: A sequential regression-neural network approach. Expert Systems with Applications, 137, 420-431 (2019)

8. M. Benner, M. Tushman, Exploitation, exploration, and process management: The productivity dilemma revisited. Academy of management review, 28(2), 238-256 (2003)

9. T. Liao, W. Lin, W. C, Corporate governance, product market competition, and the wealth effect of R\&D spending changes. Financial Management, 46(3), 717-742 (2017)

10. B. Baik, J. Chae, J, S. Choi, D. Farber, Changes in operational efficiency and firm performance: A frontier analysis approach. Contemporary Accounting Research, 30(3), 996-1026 (2013)

11. W. Greene, D. Segal, Profitability and efficiency in the US life insurance industry. Journal of Productivity Analysis, 21(3), 229-247 (2004)

12. Y. Shou, W. Hu, M. Kang, Y. Li, Y. Park, Risk management and firm performance: the moderating role of supplier integration. Industrial Management \& Data Systems (2018)

13. G. Bruton, D. Ahlstrom, J. Wan, Turnaround in East Asian firms: Evidence from ethnic overseas Chinese communities. Strategic Management Journal, 24(6), 519-540 (2003)

14. R. de Figueiredo Jr, E. Feldman, E. Rawley, The costs of refocusing: Evidence from hedge fund closures during the financial crisis. Strategic Management Journal, 40(8), 1268-1290 (2019)

15. M. Wenzel, Path dependence and the stabilization of strategi premises: How the funeral industry buries itself. Business Research, 8(2), 265-299 (2015) 
16. A. Chakrabarti, Organizational adaptation in an economic shock: The role of growth reconfiguration. Strategic Management Journal, 36(11), 1717-1738 (2015)

17. I. Reymen, P. Andries, H. Berends, R. Mauer, U. Stephan, E. Van Burg, Understanding dynamics of strategic decision making in venture creation: a process study of effectuation and causation. Strategic entrepreneurship journal, 9(4), 351-379 (2015)

18. C. Helfat, Know-how and asset complementarity and dynamic capability accumulation: the case of R\&D. Strategic management journal, 18(5), 339-360 (1997)

19. J. Brinckmann, J. Villanueva, D. Grichnik, L. Singh, L Sources of strategic flexibility in new ventures: an analysis of the role of resource leveraging practices. Strategic Entrepreneurship Journal, 13(2), 154-178 (2019)

20. N. Park, J. Mezias, Before and after the technology sector crash: The effect of environmental munificence on stock market response to alliances of e-commerce firms. Strategic Management Journal, 26(11), 987-1007 (2005)

21. J. Dyer, H. Singh, The relational view: Cooperative strategy and sources of interorganizational competitive advantage. Academy of management review, 23(4), 660-679 (1998)

22. B. Koka, J. Prescott, Strategic alliances as social capital: A multidimensional view. Strategic management journal, 23(9), 795-816 (2002)

23. W. Wan, D. Yiu, From crisis to opportunity: Environmental jolt, corporate acquisitions, and firm performance. Strategic Management Journal, 30(7), 791-801(2009)

24. A. Pablo, S. Sitkin, D. Jemison, Acquisition decision-making processes: The central role of risk. Journal of management, 22(5), 723-746 (1996)

25. P. Chattopadhyay, W. Glick, G. Huber, Organizational actions in response to threats and opportunities. Academy of Management Journal, 44(5), 937-955 (2001)

26. C. Chadwick, L. Hunter, S. Walston, Effects of downsizing practices on the performance of hospitals. Strategic Management Journal, 25(5), 405-427 (2004)

27. H. Ndofor, J. Vanevenhoven, V. Barker III, Software firm turnarounds in the 1990s: An analysis of reversing decline in a growing, dynamic industry. Strategic Management Journal, 34(9), 1123-1133 (2013) 